\title{
Рослинництво
}

\section{INFLUENCE OF HUMATES ON GROWTH, DEVELOPMENT AND FORMATION OF SUNFLOWER YIELD}

\author{
A. D. Gyrka, I. D. Tkalich, Yu. Ya. Sydorenko, O. V. Bochevar, T. V. Gyrka \\ State Institution The Institute of Grain Crops of NAAS Ukraine
}

Experimental researches were carried out in the experimental field of the laboratory of agrobiological resources of spring cereal and leguminous crops of the Erastivka experimental station of the SI The Institute of Grain Crops of the NAAS of Ukraine (SI IGC NAAN) of the Piatyhatky district of the Dnipropetrovsk region during 2016-2018 in grain-fallow-row-crop rotation after spring barley as a predecessor. Agricultural technology in experiments was common for the zone. The trial establishment, carrying out an experimental studies, records and observations, and sampling were carried out in accordance with the methodology of field experiment and the generally accepted methodical recommendations of the SI IGC NAAN. Weather conditions during the 2016-2018 for humidity and air temperature were moderately favorable for the germination of the seeds, growth and development of sunflower plants.

It was established that, depending on the variant of preparation use, compared to the control, the height of sunflower plants increased by $5.0-12.9 \mathrm{~cm}$, the diameter of the capitulum-by $2.8-4.1 \mathrm{~cm}$, the weight of seeds from the capitulum - by 2.3-4, $1 \mathrm{~g}$, weight of 1000 seeds $-6.3-8.7 \mathrm{~g}$. The best results of indicators of growth intensity, development and formation the elements of yield structure of sunflower hybrid Jason are received in a variant with foliar feeding of crops in a phase of 3-4 pairs of leaves by preparation Humivit Profi, $0.3 \mathrm{l} / \mathrm{ha}$, which provided an increase in sunflower seed yield relative to the control of $0.39 \mathrm{t} / \mathrm{ha}$. Twice foliar fertilization of sunflower crops: in the phase of 3-4 pairs of leaves - Humivit Extra and in the bud stage - Humivit Amino with application rate $0.2 \mathrm{l} / \mathrm{ha}$ of each increased the yield of sunflower seeds relative to the control by $0.23 \mathrm{t} / \mathrm{ha}$. At pre-sowing treatment of sunflower seeds with Humivit Profi, $0.3 \mathrm{l} / \mathrm{ha}$, sunflower yield was $2.23 \mathrm{t} / \mathrm{ha}$, which exceeded the control by $0.16 \mathrm{t} / \mathrm{ha}$.

Key words: sunflower, humic preparations, plant growth and development, elements of crop yield structure, crop yield.

In today's unfavorable conditions for agricultural production due to significant global warming, economic crisis, declining soil fertility, disturbance of crop rotations, chemical stress on the environment, the use of microfertilizers and growth regulators will partially sol-ve or somewhat reduce the negative effects of these phenomena [1-3].

By domestic and foreign researchers have proven the great agronomic and physiological role of plant growth regulators [4-5].

It is well-known that in the Steppe of Ukraine with unstable moisture and frequent manifestations of spring and summer droughts (under the

\section{Author information:}

Gyrka Anatoliy Dmytrovych, doctor of agricultural sciences, professor, head of the lab. of agrobiological resources of spring cereal and pulse crops, e-mail: adgyrka@gmail.com, https://orcid.org/0000-0002-2521-502X

Tkalich Igor Dmitrovich, doctor of agricultural sciences, professor, head of sciences leading researcher lab. agrobiological resources in yarich grains and legumes, e-mail: inst_zerna@ukr.net, http://orcid.org/0000-0003-0736-3667

Sydorenko Yuriy Yakovich, cand. of agricultural sciences, senior scientist of science, leading researcher lab. agrobiological resources in grain and leguminous crops: e-mail: zernovik1 @ukr.net, https://orcid.org//0000-0003-0695-3956

Bochevar Olga Volodymyrivna, cand. of agricultural sciences, senior scientist of science, leading researcher lab. agrobiological resources in arich cereals and leguminous crops, e-mail: olgamedodessa@ukr.net, https://orcid.org/0000-0001-5549-7681

Gyrka Tetiana Volodymyrivna, cand. of agricultural sciences, senior researcher, leading researcher of the laboratory of plant protection, e-mail: tvgyrka@gmail.com, https://orcid.org/0000-0002-5769-3384 
influence of global warming), the use of mineral fertilizers for all crops, including sunflower is not effective enough. Therefore, there is a need to develop alternative measures to increase the efficiency of mineral nutrition of plants by studying the effects of plant growth regulators, micronutrients, physiologically active sub stances, etc. [6-9].

The aim of the study was to study the effect of humates in combination with physiologically active substances and microelements (preparations: Humivit Profi, Humivit Extra and Humivit Amino) on sunflower plants.

To achieve this goal, the research program envisaged to study the features of growth, development and formation the sunflower crop yield depending on the timing and methods of application the Humivit Profi, Humivit Extra and Humivit Amino; to find out the effectiveness of using these preparations at seed treatment before sowing and in the conditions of application during the growing season; determine the individual productivity and crop yield of sunflower plants depending on the use of Humivit Profi, Humivit Extra and Humivit Amino.

Object of research: processes of growth, development and formation of sunflower crop yield depending on the terms and methods of application of Humivit Profi, Humivit Extra and Humivit Amino.

Subject of research: sunflower plants of Jason hybrid, terms and methods of application the Humivit Profi, Humivit Extra and Humivit Amino, elements of crop yield structure, level of crop yield.

Material and methods. The soil cover of the Erastivka Experimental Station of the Institute of Grain Crops of NAAS of Ukraine (hereinafter - Erastivka ES of SI IGC of NAAS) is represented by ordinary low-humus heavy loam chernozem and their lightly washed types.

The main agrochemical properties of these chernozem, according to the agrochemical laboratory of the station, are characterized by the following indicators. The humus content in the arable layer varies from 4,0 to $4,5 \%$. The gross content of nutrients in the arable layer of chernozem varies within the following limits: nitrogen - from 0,23 to $0,26 \%$, phosphorus - from 0,11 to $0,16 \%$, potassium - from 2,0 to $2,5 \%$. The structure of the arable layer is dusty-lumpy, the subsoil layer is lumpy-granular. The number of water-resistant units in the arable layer is 40$50 \%$, in the subsoil - 55-65\%. The climate of the zone is temperate-continental, characterized by aridity and unstable humid conditions. According to long-term data of the Comisarivka Meteorological Station, which is located on the territory of the Experimental Station, the average annual rainfall is $435 \mathrm{~mm}$. The spring period is marked by an intense rise in temperature, which leads to rapid melting of snow, thawing and warming of the soil, and is often characterized by aridity, which inhibits seed germination, growth and development of crops.

Research work was carried out in grainfallow-row crop rotation after the predecessor of spring barley. Agricultural growing measures in experiments were generally accepted for the zone. After harvesting the predecessor, the stubble was primary tillaged twice, followed by plowing to a depth of $20-22 \mathrm{~cm}$. Spring tillage consisted of early spring harrowing and presowing cultivation. Sowing of sunflower was carried out with a seeder SUPN-8 in a singlegrain sowing manner, followed by rolling the sown areas. A set of preparations were used by treating sunflower seeds before sowing (Humivit Profi, 0,8 1/t) and applying in the phase of 34 pairs of leaves (Humivit Extra, 0,2 1/ha) or (Humivit Profi, 0,3 1/ha) and in the bud formation phase (Humivit Amino, 0,2 1/ha). Aqueous spray materials of the studied preparations were prepared on the day of application. For pre-sowing treatment of seeds, the recommended doses of preparations per 1 ton of seeds were dissolved in 8 liters of water (semi-dry method of treatment). Placement of variants is systematic with three replications. The sown area of the sunflower plot was $56 \mathrm{~m}^{2}$.

Establishment of a trials, conducting the experimental researches, accountings and observations, sampling were performed in accordance with the methods of field research and generally accepted methodological recommendations of SI IGC of NAAS [10-11].

Weather conditions during 2016-2018 in terms of humidity and air temperature were moderately favorable for seed germination, growth and development of sunflower plants.

Results and discussion. In the experiment, sunflower of the Jason hybrid was sown 5.05 in 2016, 11.05 - in 2017, and 7.05 - in 2018. By the investigations stated that the use 
of the studied preparations (Humivit Profi, Humivit Extra and Humivit Amino) did not have a significant effect on the timing and duration of the main phenological phases of development of sunflower plants (Table 1).

Thus, the phase of full sunflower germination was observed in the second half of May, namely: 16 - in 2016, on May, 29 and 20 - respectively in 2017 and 2018. The timing of the next phases of development was significantly influenced by air temperatures and moisture content of the interphase periods. Thus, the phases of bud formation and flowering in 2016 were observed on 24.06 and 14.07, in 2017 5.07 and 20.07, and in $2018-18.06$ and 13.07, respectively. Harvesting operations were made in the phase of full ripeness at a seed moisture of $9 \%$, respectively $-9.09,12.09$ and 12.09.

\section{Dates of the main phenological phases of growth and development of sunflower plants, hybrid Yason}

\begin{tabular}{|c|c|c|c|c|}
\hline Sowing & Germination & Bud formation & Flowering & Full ripeness \\
\hline \multicolumn{5}{|c|}{$2016 \mathrm{p}}$. \\
\hline 05.05 & 16.05 & 24.06 & 14.07 & 09.09 \\
\hline \multicolumn{5}{|c|}{$2017 \mathrm{p}}$. \\
\hline 11.05 & 29.05 & 05.07 & 20.07 & 12.09 \\
\hline \multicolumn{5}{|c|}{$2018 \mathrm{p}}$. \\
\hline 07.05 & 20.05 & 18.06 & 13.07 & 12.09 \\
\hline
\end{tabular}

Cool weather at the beginning of the sunflower growing season negatively affected the field germination of seeds, which was $85-87 \%$. After the formation of standing density, the number of plants per unit area of all variants was 56 thousand/ha. This made it possible to identify features of growth and development of the culture under the influence of the studied preparations.

Determining the elements of the sunflower yield structure in the experiment showed a positive effect of the use of humic preparations (Humivit Profi, Humivit Extra and Humivit
Amino) on the growth and development of crop plants. Under the action of these humates significantly changed the height of plants, the diameter of the capitulum and the weight of the seeds. Thus, in the variant without seed treatment and top dressing crops (control), the height of sunflower plants was $178,7 \mathrm{~cm}$, the diameter of capitulum $-16,4 \mathrm{~cm}$, the weight of seeds from the capitulum $-53,0 \mathrm{~g}$, the weight of 1000 seeds 53,8 g. At treatment of sunflower seeds with Humivit Profi with a consumption rate of $0,81 / \mathrm{t}$, these indicators increased by $5,0 \mathrm{~cm} ; 2,8 \mathrm{~cm}$; $2,3 \mathrm{~g}$ and $6,3 \mathrm{~g}$, respectively (Table 2 ).

\section{Elements of the sunflower yield structure of hybrid Yason depending on the methods of application the preparations (average for 2016-2018)}

\begin{tabular}{|c|c|c|c|c|}
\hline № & Plant height, cm & $\begin{array}{c}\text { Diameter } \\
\text { of capitulum, cm }\end{array}$ & $\begin{array}{c}\text { Weight of seeds from } \\
\text { the capitulum, } \mathrm{g}\end{array}$ & $\begin{array}{c}\text { Weight of 1000 seeds, } \\
\mathrm{g}\end{array}$ \\
\hline 1. & 178,7 & 16,4 & 53,0 & 53,8 \\
\hline 2. & 183,7 & 19,2 & 55,3 & 60,1 \\
\hline 3. & 186,8 & 20,0 & 56,8 & 62,5 \\
\hline 4. & 191,6 & 20,5 & 57,1 & 59,2 \\
\hline
\end{tabular}

Top dressing of sunflower crops with humic preparations, studied in the experiment proved to be more effective than pre-sowing seed treatment. With the help of this agricultural measure, the height of sunflower plants increased relatively to the control by $8,1-12,9 \mathrm{~cm}$, the diameter of the capitulum - by $3,6-4,1 \mathrm{~cm}$, the weight of seeds from the capitulum - by $3,8-4,1 \mathrm{~g}$, the weight of 1000 seeds - by $5,4-8,7$ $\mathrm{g}$ (in variants 3,4$)$.
According to the high productivity of plants in these variants observed also the highest crop yield of sunflower seeds in the experiment. Thus, one-time spraying of crops in the phase of 3-4 pairs of leaves with Humivit Profi, 0,3 1/ha was the most effective and contributed to the increase of sunflower crop yield compared to the control variant by $0,39 \mathrm{t} / \mathrm{ha}$. Under conditions of double top dressing of sunflower crops: in the phase of 3-4 pairs of leaves - Humivit 
Extra and in the bud formation phase - Humivit Amino with a consumption rate of 0,2 1/ha of each preparation, the increase in seed yield compared to the best variant of the experiment decreased by $0,16 \mathrm{t} / \mathrm{ha}$, and relatively to control - increased by 0,23 t/ha (Table 3 ).

\section{Crop yield of sunflower seeds of hybrid Yason depending on the methods of application the prepara- tions (average for 2016-2018)}

\begin{tabular}{|c|c|c|c|c|}
\hline \multirow{2}{*}{ № } & \multirow{2}{*}{ Application schedule } & \multirow{2}{*}{$\begin{array}{c}\text { Crop yield } \\
\text { of seeds, } \mathrm{t} / \mathrm{ha}\end{array}$} & \multicolumn{2}{|c|}{ Yield increase } \\
\hline & & & $\mathrm{t} / \mathrm{ha}$ & $\%$ \\
\hline 1. & Control (without seed treatment and top dressing) & 2,57 & - & - \\
\hline 2. & Pre-sowing seed treatment with Humivit Profi, $0,8 \mathrm{l} / \mathrm{t}$ & 2,73 & 0,16 & 6,23 \\
\hline 3. & One-time top dressing of crops with Humivit Profi, $0,3 \mathrm{l} / \mathrm{ha}$ & 2,96 & 0,39 & 15,18 \\
\hline 4. & $\begin{array}{l}\text { Double top dressing of crops: } 1 \text { st - with Humivit Extra, } \\
0,2 \text { 1/ha; } 2 \text { nd - with Humivit Amino, } 0,2 \text { 1/ha }\end{array}$ & 2,80 & 0,23 & 8,95 \\
\hline \multicolumn{2}{|c|}{$\mathrm{LSD}_{0,05}, \mathrm{t} / \mathrm{ha}$} & 0,07 & - & - \\
\hline
\end{tabular}

In terms of temperature and humidity, the year was moderately favorable for the development and spread of diseases. In some fields in the production conditions it was possible to observe the defeat of plants by Fusarium wilt, sunflower broomrape, powdery mildew, phomosis and leaf spot: Septoria, cercosporosis, white and gray rot. But in the conditions of experiments the manifestation of these diseases was almost not noted. Sunflower was damaged in small quantities by weevils, copperheads, aphids, but plant damage did not exceed the level of economic threshold of harmfulness (ETH).

\section{Conclusions}

The results of research conducted during 2016-2018 allow us to draw the following conclusions:

1. Weather conditions in 2016-2018 in terms of humidity and air temperature were moderately favorable for seed germination, growth and development of sunflower plants of hybrid Yason, which was used in the experiment.

2. Humic preparations Humivit Profi, Humivit Extra and Humivit Amino for presowing seed treatment $(0,8 \mathrm{l} / \mathrm{t})$ and top dressing of sunflower plants of hybrid Yason in phases of 3-4 pairs of leaves and bud formation (0,2 1/ha) were not carried out significant impact on the timing and duration of the main phenologi-

\section{Використана література}

1. Ткаліч І. Д., Гирка А. Д., Бочевар О. В., Ткаліч Ю. І. Агротехнічні заходи підвищення урожайності насіння соняшника в умовах Степу України. Зернові культури. 2018. Т. 2. № 1. С. 44-52

2. Кохан А. В., Ткалич Ю. І. Фізіологічно-активні речовини в технології вирощування соняшнику. Пропозичія. 2011. № 5. С. 86-67. cal phases of development of crop plants.

3. The use of humic preparations Humivit Profi, Humivit Extra and Humivit Amino in the technology of growing sunflower hybrid Yason has a positive effect on the formation of biometric indicators and elements of the crop yield structure. Depending on the variant of preparation use, compared to the control, the height of sunflower plants increased by $5,0-12,9 \mathrm{~cm}$, the diameter of the capitulum - by $2,8-4.1 \mathrm{~cm}$, the weight of seeds from the capitulum - by 2,3$4.1 \mathrm{~g}$, weight of 1000 seeds - by 6,3-8,7 g.

4. Higher crop yield of sunflower seeds of hybrid Yason in the experiment was obtained in the variant with top dressing of crops in the phase of 3-4 pairs of leaves with the preparation Humivit Profi, 0,3 1/ha. In this variant of the experiment, the increase in crop yield of sunflower seeds relatively to the control was $0,39 \mathrm{t} / \mathrm{ha}$. Double top dressing of sunflower crops: in the phase of 3-4 pairs of leaves - Humivit Extra and in the bud formation phase - Humivit Amino with a consumption rate of $0,21 /$ ha for each preparation helped to increase the crop yield of sunflower seeds relatively to the control by 0,23 t/ha. During pre-sowing treatment of sunflower seeds with Humivit Profi, 0,3 1/ha, sunflower crop yield was $2 ., 23 \mathrm{t} / \mathrm{ha}$, which is higher than the control by $0,16 \mathrm{t} / \mathrm{ha}$.

3. Ткалич И. Д. Ткалич Ю. И., Рычик С. Г. Цветок солнца (основы биологии и агротехники подсолнечника): монография / под ред. док-ра с.-х. наук, проф. И. Д. Ткалича. Днепропетровск, 2011. 172 с.

4. Грицаєнко 3. М., Пономаренко С. П., Карпенко В. П., Леонтюк І. Б. Біологічно активні речовини в рослинництві / за ред. 3. М. Грицаєнко; Уманський 
держ. аграр. ін-т, 2008. 346 с.

5. Поляков О. І., Нікітенко О. В. Вплив інкрустації насіння соняшнику сорту Прометей на його схожість та продуктивність. Наук.-тех. бюл. Ін-ту олійних культур. 2002. Вип. 7. С. 151-153.

6. Ткаліч І. Д., Ткаліч Ю. І., Кохан А. В. Вплив способів сівби, прийомів догляду і добрив на врожайність насіння соняшнику в Степу. Бюл. Iн-ту сіл. госn-ва cmen. зони. 2012. № 2. С. 128-132.

7. Аксёнов И. В. Агроприемы выращивания и урожайность подсолнечника. Науч.-тех. бюл. Ин-та масличных культур. 2004. Вып. 9. С. 155-161.

8. Краевский А.Н. Альтернативная технология возделывания подсолнечника. Науч.-тех. бюл. Ин-та масличных культур УААН. 2009. Вып. 14. С. 167-

\section{References}

1. Tkalich, I. D., Gyrka, A. D., Bochevar, O. V., Tkalich, Yu. I. (2018). Agrotechnical measures to increase the productivity of sunflower seeds in the conditions of the steppe of Ukraine. Zernovi kultury [Grain Crops], 2, 1. 44-52. [in Ukrainian]

2. Kokhan, A. V., Tkalych, Yu. I. (2011). Physiologically active substances in the technology of sunflower growing. Propozytsiya [Proposal], 5, 86-67. [in Ukrainian]

3. Tkalich, I. D. Tkalich, Yu. I., Rychik, S. G. (2011). Tsvetok solntsa (osnovy biologii i agrotekhniki podsolnechnika) [The Flower of the Sun (fundamentals of biology and agrotechnology of sunflower)]. Dnepropetrovsk: N. p. 172. [in Russian]

4. Hrytsayenko, Z. M., Ponomarenko, S. P, Karpenko, V. P., Leontyuk, I. B. (2008). Biolohichno aktyvni rechovyny $v$ roslynnytstvi [Biologically active substances in crop production]. Uman State Agrarian Institute. 346 p. [in Ukrainian]

5. Polyakov, O. I., Nikitenko, O. V. (2002). Influence of inlaid seeds of sunflower of the Prometei variety on its germination ability and productivity. Naukovotehnichnyi buleten Instytutu oliynyh kultur [Scientific and technical bulletin of the Institute of Oilseeds], 7, 151-153. [in Ukrainian]

6. Tkalich, I. D., Tkalich, Yu. I., Kokhan, A. V. (2012). Influence of sowing methods, methods of care and fertilizers on yield of sunflower seeds in the Steppe. Buleten Instytutu stepovoi zony [Bulletin of the Steppe Zone Institute], 2, 128-132. [in Ukrainian]

7. Aks'onov, I. V. (2004). Agricultural methods of cul-
171.

9. Бондаренко М. П. Вплив агротехнічних прийомів на урожайність і якість насіння соняшнику в умовах північно-східного Лісостепу України: автореф. дис. ... канд. с.-г. наук. Дніпропетровськ, 2003. $19 \mathrm{c}$.

10. Доспехов Б. А. Методика полевого опыта (с основами статистической обработки результатов исследований). 5-е изд., доп. и перераб. Москва: Агропромиздат, $1985.352 \mathrm{c.}$

11. Методические рекомендации по проведению полевых опытов с зерновыми, зернобобовыми и кормовыми культурами / под ред. В. С. Цыкова и Г. Р. Пикуша. Днепропетровск, 1983. 46 с.

tivation and yield of sunflower. Naukovo-tehnichnyi buleten Instytutu maslichnyh kultur [Scientific and technical bulletin of the Institute of Oilseeds], 9, 155-161. [in Russian]

8. Krayevskiy, A. N. (2009). Al'ternativnaya technologiya vozdelyvaniya podsolnechnika [Alternative sunflower cultivation technology]. Naukovo-tehnichnyi buleten Instytutu maslichnyh kultur [Scientific and technical bulletin of the Institute of Oilseeds], 14, 167-171. [in Russian]

9. Bondarenko, M. P. (2003). Vplyv ahrotekhnichnykh pryyomiv na urozhaynist $i$ yakist nasinnya sonyashnyku $v$ umovakh pivnichno-skhidnoho Lisostepu Ukrayiny [The influence of agrotechnical methods on yield and quality of sunflower seeds in the conditions of the northeastern forest-steppe of Ukraine]. Dnipropetrovsk: N. p. 19 p. [in Ukrainian]

10. Dospekhov, B. A. (1985). Metodika polevogo opyta s osnovami statisti-cheskoy obrabotki rezul'tatov issledovaniy [Methodology of field experience with the basics of statistical processing of research results] $\left(5^{\text {th }}\right.$ ed. rev.). Moscow: Ahropromizdat. 352 p. [in Russian]

11. Metodicheskiye rekomendatsii po provedeniyu polevykh opytov s zernovymi, zernobobovymi i kormovymi kul'turami [Methodical recommendations for carrying out field experiments with grain, leguminous and fodder crops] (1983) / V. S. Tsykov and G. R. Pikush (Eds.). Dnepropetrovsk: N. p. 46 p. [in Russian]

\section{УДК 633.854.78:631.416.9}

Гирька А. Д., Ткалич И. Д., Сидоренко Ю. Я., Бочевар О. В., Гирька Т. В. Влияние гуматов на рост, развитие и формирование урожайности подсолнечника.

Зерновые культуры. 2020. T. 4. № 2. С. 251-256.

Государственное учреждение Институт зерновых культур НААН, ул. Владимира Вернадского, 14, г. Днепр, 49027, Украина

Экспериментальные исследования проводили на опытном поле лаборатории агробиологических ресурсов яровых зерновых и зернобобовых культур Эрастовской опытной станции Государственного учреждения Институт зерновых культур НААН (ГУ ИЗК НААН) на протяжении 20162018 г2. в зерно-паро-пропашном севообороте после предшественника ячмень яровой. Агротехника в опытах - общепринятая для зоны. Закладку опытов, экспериментальные исследования, учет и 
наблюдения, отбор образиов выполняли в соответствии с методикой полевого опыта и общепринятыми методическими рекомендаџиями ГУ ИЗК НААН. Погодные условия на протяжении 20162018 г2. по увлажнению и температуре воздуха были среднеблагоприятными для прорастания семян, роста и развития растений подсолнечника.

Установлено, что в зависимости от варианта использования препаратов, высота растений подсолнечника увеличилась на 5,0-12,9 см, диаметр корзинки - на 2,8-4,1 см, масса семян из корзинки - на 2,3-4,1 2, масса 1000 семян - на 6,3-8,7 г по сравнению с контролем. Лучшие результать относительно интенсивности роста, развития и формирования элементов структуры урожсайности подсолнечника гибрида Ясон получены в варианте с внекорневой подкормкой посевов культуры в фазе 3-4 пары листьев препаратом Гумивит Профи, 0,3 л/2а - прирост урожсайности семян подсолнечника относительно контроля составил 0,39 $\mathrm{m} / 2$. Двукратная внекорневая подкормка посевов подсолнечника в фазе 3-4 пары листьев препаратом Гумивит Экстра и в фазе звездочки - Гумивит Амино с нормой расхода каждого 0,2 л/га способствовала приросту урожайности семян относительно контроля на 0,23 m/2a. В случае предпосевной обработки семян препаратом Гумивит Про$\phi и, 0,3$ л/га урожайность подсолнечника составила $2,23 \mathrm{~m} / 2$, что превысило контроль на 0,16 m/2a.

Ключевые слова: подсолнечник, гуминовые препараты, рост и развитие растений, элементы структуры урожсайности, урожайность семян.

УДК 633.854.78:631.416.9

Гирка А. Д., Ткаліч І. Д., Сидоренко Ю. Я., Бочевар О. В., Гирка Т. В. Вплив гуматів на ріст, розвиток і формування врожайності соняшника.

Зернові культури. 2020. T. 4. № 2. С. 251-256.

Державна установа Інститут зернових культур НААН, вул. Володимира Вернадського, 14,

м. Дніпро, 49027, Украӥна

Експериментальні дослідження проводили на дослідному полі лабораторії агробіологічних ресурсів ярих зернових і зернобобових культур Ерастівської дослідної станції Державної установи Інститут зернових культур НААН (ДУ ИЗК НААН) впродовж 2016-2018 рр. в зерно-паро-просапній сівозміні після попередника ячмінь ярий. Агротехніка у дослідах - загальноприйнята для зони. Закладку дослідів, експериментальні дослідження, обліки, спостереження, відбір зразків виконували відповідно до методики польового досліду та загальноприйнятих методичних рекомендаиій ДУ ІЗК НААН. Погодні умови впродовж 2016-2018 рр. за зволоженням і температурою повітря були середньосприятливими для проростання насіння, росту і розвитку рослин соняшника.

Встановлено, що залежно від варіанту використання препаратів, висота рослин соняшника збільшилась на 5,0-12,9 см, діаметр кошика - на 2,8-4,1 см, маса насіння з кошика - на 2,3-4,1 2, маса 1000 насінин - на 6,3-8,7 г порівняно з контролем. Кращі результати відносно інтенсивності росту, розвитку та формування елементів структури врожайності насіння сонямника гібрида Ясон були одержані у варіанті з позакореневим підживленням посівів у фазі 3-4 пари листків у культури препаратом Гумівіт Профі, 0,3 л/га - приріст урожайності насіння соняшника відносно контролю становив 0,39 m/2а. Дворазове позакореневе підживлення посівів у фазі 3-4 пари листків у соняшника препаратом Гумівіт Екстра і в фазі зірочки - Гумівіт Аміно з нормою витрати кожного 0,2 л/га зумовило приріст урожайності насіння відносно контролю на $0,23 \mathrm{~m} / 2 \mathrm{a}$. За передпосівної обробки насіння препаратом Гумівіт Профі, 0,3 л/га урожайність соняшника становила 2,23 m/2а, що перевищило контроль на 0, $16 \mathrm{~m} / 2$.

Ключові слова: соняшник, гумінові препарати, ріст і розвиток рослин, елементи структури врожайності, урожайність насіння. 